\title{
A STUDY ON OPEN BUILDING IMPLEMENTATION THROUGH APARTMENT ADAPTATION IN SAO PAULO, BRAZIL
}

\author{
ブラジル・サンパウロ市の集合住宅における住戸改造からみた SI ハウジングシステムに関する研究
}

\author{
Marianne COSTA*, Jiyoung JUNG **, Hidekazu FUJIMOTO*** \\ and Hideki KOBAYASHI**** \\ コスタマリアンネ，丁 志 映，藤本秀一，小林秀樹
}

In Brazil, since informal and self-managed construction projects are compromising the individual and collective scale of multi-story apartment construction, this study aims to clarify the nation's support and infill (SI) system division, as well as its implementation requirements, in terms of housing demands, national laws, and the development level of the housing industry. To accomplish this, 16 remodeled apartments were examined and interviews were conducted with a number of Sao Paulo real estate developers and managers. The results showed the following: 1) self-managed adaptation is not only related to infill, but also to support level decisions; 2) local building legislation, condominium bylaws, and the available building systems are unresponsive to actual user demands and the decision-making processes.

Keywords: Apartment Building, Support Infill System, Dwelling Improvement, Brazil 集合住宅, SI ハウジングシステム, 住戸改造, ブラジル

\section{Introduction}

\section{(1) Research Background and Purpose}

This study is based on Open Building concept ${ }^{11}$, and more particularly, on the SI System principle ${ }^{23) 4}$, which separates decision-making in a residential environment, according to a subsystems approach that distinguishes parts that should adapt according to the user's needs (Infill) and parts that should endure (Support). This basis has turned dwellings into user-oriented goods in Japan and could be restructured to bind benefits of industrial progress and new societal values in Brazil.

Currently, there is little background about Open Building in Brazil. The most closely related speculation was written by Brandao ${ }^{5)}$ as part of a study on apartment spatial flexibility, and by Nascimento et al.6) in a study on the open building approach for social housing. Accordingly, there is little evidence on apartment adaptation towards Open Building notions.

In Brazil, multi-story dwellings have long been dismissed from housing programs as unable of providing decent home conditions for low-income people ${ }^{7}$. Rather, innovative housing concepts have always first been experienced by high-income families ${ }^{8}$. I.e., multi-story housing used to be a custom-built product for Brazilian higher income classes, even though such typology does not hold an elitist connotation in its origins.
Now, the structure and partitions of Brazilian apartments are primarily built with masonry because this method is inexpensive and meets the low-income housing demand. However, the technique offers low adaptability and unclear support and infill (SI) division. Furthermore, regardless of the household's income, most renovations are self-managed ${ }^{9}$, and it should be noted that, even though remodeling regulations exist, condominium decisionmaking is typically organized in homeowners associations $(\mathrm{HOAs})^{* 1}$, and is thus usually managed by unskilled chairpersons (Law 4,591, 1964). Since such informal construction management have come to threaten the individual and collective scale of apartment buildings ${ }^{10111}$, this study aims to clarify the SI system division in Brazil, as well as its applicability by observation of remodeled apartments.

(2) Research Questions

1) In Brazil, dwelling adaptation is commonplace ${ }^{7122)}$. Are renovation purposes in Brazil different from those in Japan?

2) Brazil is not as earthquake prone as Japan ${ }^{13)}$, thus building policies can be less restrictive. Does this mean that Brazilian dwellers have more options and/or can remodel more often?

3) The recent growth of the Brazilian economy has been widely noticed and discussed in many aspects ${ }^{14) 15}$. How does this economic activity create opportunities for home adaptation?

\footnotetext{
* Grad. Stud., Department of Urban Environment Systems, Chiba University, M. Eng.

** Assist. Prof., Department of Urban Environment Systems, Chiba University, Ph. D.

*** Research Director, National Institute for Land and Infrastructure Management, M. Eng.

**** Prof., Department of Urban Environment Systems, Chiba University, Dr. Eng.
}

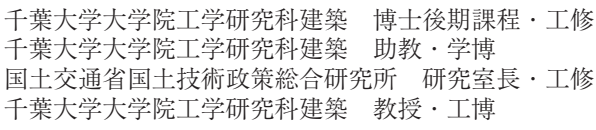


(3) Housing Stock Classification and Urban Context of Sao Paulo Throughout its history, Brazil's housing policies have emphasized the promotion of home ownership in formal markets as the best way of meeting the housing needs of the population, thereby assigning an inferior status to rental units ${ }^{16)}$. As a result, the housing stock Brazil is primarily owned, regardless of household income. Compared to the sum of detached dwellings, apartment availability is very low at metropolitan and national levels. Also, these apartments are concentrated in the city center and mostly belong to the upper-middle-class income population (Figs. 1 \& 2).
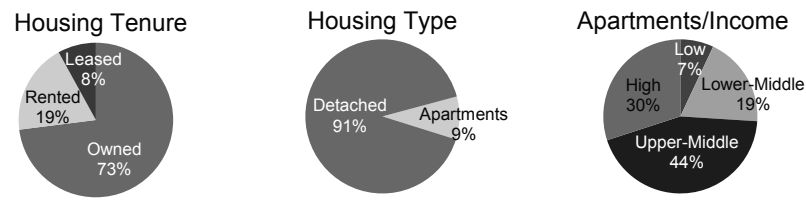

Fig.1 National Housing Stock Classification ${ }^{17}$

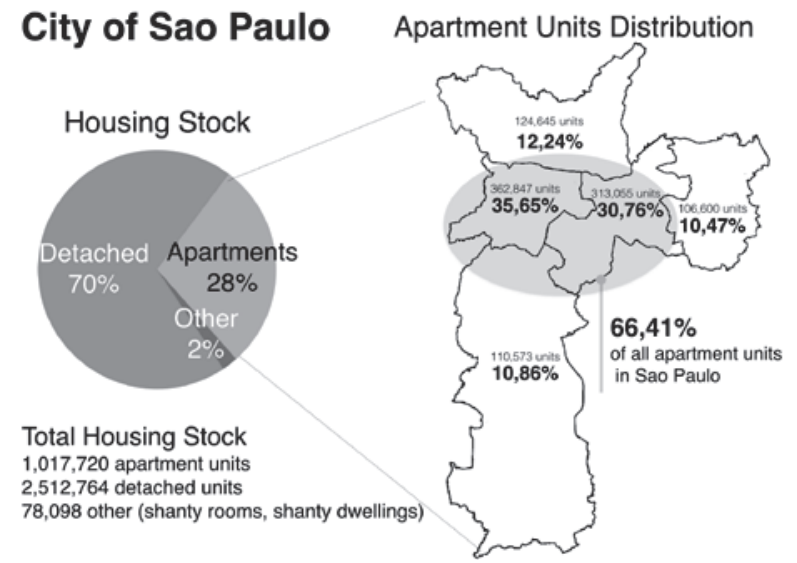

Fig. 2 Apartment Stock of Sao Paulo ${ }^{18)}$

Since the late 1980s, downtown Sao Paulo has been undergoing a renovation in order to keep it within the network of global cities. The renewal strategies have caused an increase in property values, resulting in urban gentrification. Hence, some groups are experiencing conflicts of interest between state, market, and popular classes, often relating to segregation and safety issues.

\section{Survey Outline}

This research is focused on remodeled upper-middle-class owned apartments in the center of the city of Sao Paulo (Table 1). Fieldwork activities were carried from July 11 to 31, 2012, as outlined in Table 2, with the help of two architectural students. Due to the social gap and urban issues already mentioned, Sao Paulo residents are very suspicious of outsiders. Thus, the investigation was built on observations of 16 remodeled homes selected through snowball sampling (friends referring to friends). Even though the representativeness of the samples could be questionable, it could be assumed that the data had little bias, as shown in Fig. 5, which confirms a user stratification profile that is similar to the national level, as is shown in Figs. 1 and 2.
Table 1 Samples: 10 condominiums; 16 adapted units

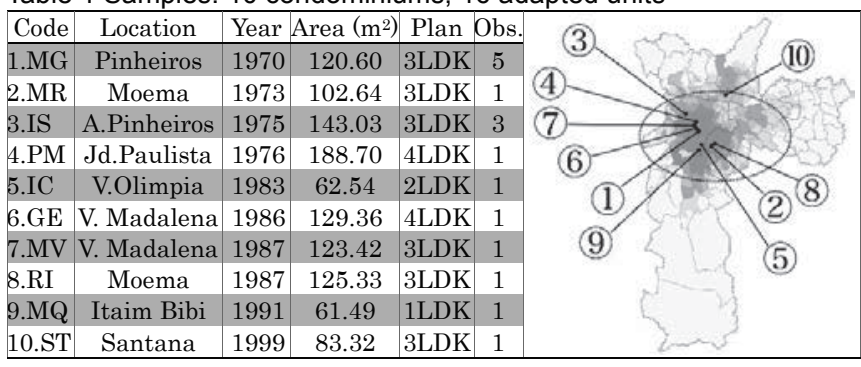

Table 2 Survey Outline

\begin{tabular}{|c|c|c|c|}
\hline$\overline{\mathrm{Sch} \epsilon}$ & -17 & 20 & \\
\hline Purpose & background info. & preparation work & \\
\hline Sub & $\begin{array}{c}3 \text { develop } \\
\text { makers }\end{array}$ & & $\begin{array}{r}16 \\
(10\end{array}$ \\
\hline $\begin{array}{r}\text { etiviti } \\
\text { Docs }\end{array}$ & $\begin{array}{l}\text { views, } \\
\text { flyers, etc. }\end{array}$ & $\begin{array}{l}\text { minium } \\
\text { legislatio }\end{array}$ & $\begin{array}{l}\text { ews, photos, } \\
\text { sketches, etc. }\end{array}$ \\
\hline
\end{tabular}

\section{Management of Adaptations in Apartment Buildings}

Several agents make up the contemporary real estate market and handle all work related to the production and adaptation of multi-story dwellings in Brazil. Based on previous studies and interviews with company agents in Sao Paulo ${ }^{8) 19)}$, adaptation management could be classified into the before and after key delivery stages (Fig. 3)

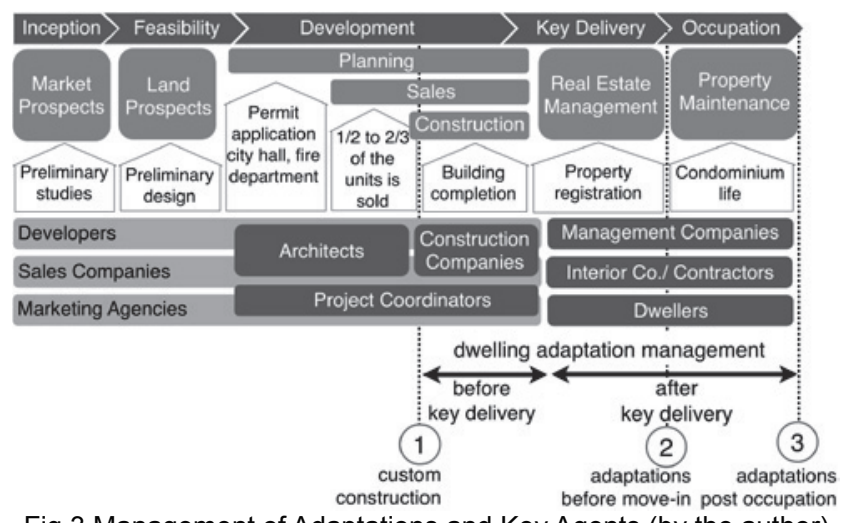

Fig.3 Management of Adaptations and Key Agents (by the author)

(1) Adaptations before Key Delivery (custom construction)

Company interviews revealed that adaptation management before key delivery is based on pre-set design options, from which the dweller can choose the floor plan layout (free of charge) and finishing options, such as flooring, tiling, basin, toilet, and sink (with additional fees)

\section{(2) Adaptations after Key Delivery}

Although most works are self-managed after key delivery, some contracts include professional management. For our upcoming analysis, after key delivery adaptations were classified by the engagement of technical expertise relating to the design, building, or on-site management stages (Table 3).

Table 3 Management Methods According to Contract Type

\begin{tabular}{|c|c|c|c|c|}
\hline Contrac & Design & Building & Management & Method \\
\hline DIY & Dweller & Dweller & Dweller & \multirow{3}{*}{$\begin{array}{c}\text { Self- } \\
- \text { Management }\end{array}$} \\
\hline B & Dweller & Contractor & Dweller & \\
\hline DB & Designer/Contractor & Contractor & Dweller & \\
\hline $\mathrm{BM}$ & Dweller/Contractor & Contractor & Contractor & Professional \\
\hline DBM & Designer & Contractor & Contractor/Design & Management \\
\hline
\end{tabular}




\section{Sampling Characterization}

(1) Household's Profile

Of 16 households observed, 15 are owned, and one is rented. Nuclear families purchased 10 of the owned units. These families, however, have matured or developed into other arrangements and now are equally distributed into four major family structures. Buildings age from 23 to 44 years, and years of residence vary from 2 to 41 . Unit areas vary from $61.5 \mathrm{~m}^{2}$ to $188.7 \mathrm{~m}^{2}$, and the number of dwellers per unit ranges from 1 to 5 people (Table 4).

\section{Table 4 Households Profile}

SampleMove-No. of Tenure Family Structure No. of Dwellers Household

Code in Adapt. Original Current OriginalCurrent Income

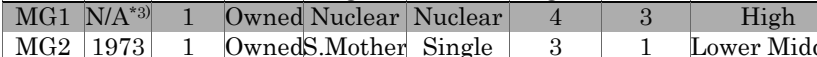

MG3 1990 3 Owned Nuclear Couple $\quad 4 \quad 4$ Upper Middle

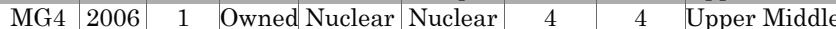

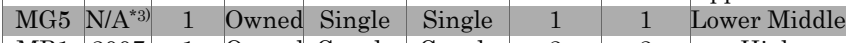

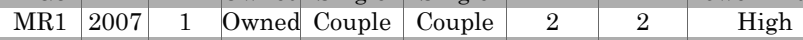

\begin{tabular}{l|l|l|l|l|l|l} 
IS1 & 2011 & 1 & Rented Nuclear Nuclear & 4 & 5 & Upper Middle
\end{tabular}

\begin{tabular}{l|l|l|l|lll} 
IS2 & 2010 & 1 & OwnedS.MothenS.Mother & 5 & 4 & Upper Middle
\end{tabular}

\begin{tabular}{c|c|cl|lll} 
IS3 & 1993 & 5 & Owned Nuclear S.Mother & 5 & 4 & Upper Middle
\end{tabular}

\begin{tabular}{l|l|ll|ll|l} 
PM1 & 1999 & 1 & Owned Nuclear S.Mother & 5 & 3 & Upper Middle
\end{tabular}

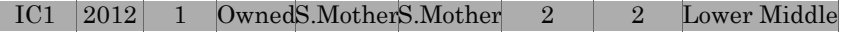

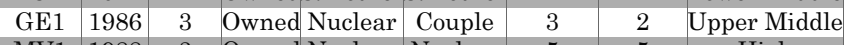

\begin{tabular}{|l|l|l|l|l|l|l|} 
MV1 & 1988 & 3 & Owned Nuclear Nuclear & 5 & 5 & High \\
\hline
\end{tabular}

\begin{tabular}{l|l|ll|l|ll|l} 
RI1 & 1988 & 3 & Owned Nuclear & Couple & 4 & 2 & Upper Middle
\end{tabular}

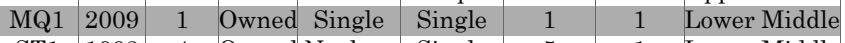
\begin{tabular}{c|c|cl|l|l|l|l|} 
ST1 & 1992 & 4 & Owned Nuclear & Single & 5 & 1 & Lower Middle \\
\hline
\end{tabular} N/A: Not Available; Income per Monthly Wage ${ }^{*}$

S. Mother: Single Mother See Figure 5

Still, according to interviews, $50 \%$ of the householders were temporary residents. Within households with permanent purpose, the reason for moving in was primarily associated with relationship enhancement, such as having a larger space to raise children, or to be near the householder's parents. In turn, within households with temporary aspect, the reason for moving in was more associated with evading a previous condition, i.e., personal independence, changing jobs, or departing from other neighborhoods for safety reasons (Fig. 4).
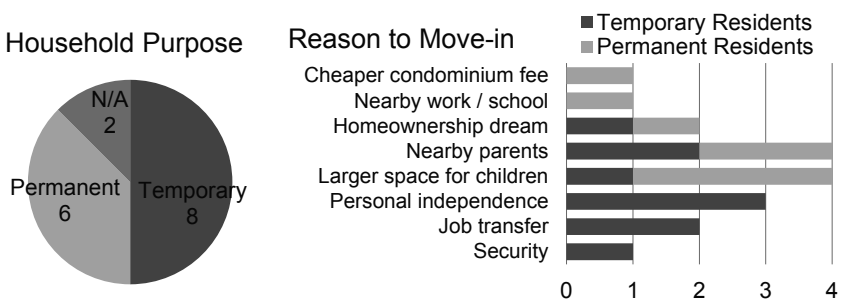

Fig.4 Household Condition and Purpose

The dwellers were mostly between 30 to 59 years old (16 people), followed by elderly persons aged 60 years or older (10 people). Nine cases consisted of prior residents that had grown up, divorced and moved out, or passed away, indicating households' maturity. Based on monthly income, these families could be split in three groups ${ }^{*}{ }^{*}$ ): high, upper-middle, and lower-middle (Fig. 5).

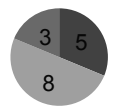

- Lower Middle Income $(\$ 1,036-\$ 4,085)$

- Upper Middle Income $(\$ 4,086-\$ 12,615)$

- High Income (\$12,616 or more)

Fig. 5 Households Income Classification

\section{(2) Original Floor Plan Features}

The model used for most contemporary Brazilian dwellings is based on the $19^{\text {th }}$ century bourgeois concept of three parts: social, service, and personal ${ }^{5}$. The sampling showed typical floor plans, mainly built with three-bedrooms, one of which is a suite. The suite comprises of a master bedroom, often larger than the others, and a private bathroom. Additionally, the presence of the maid's room indicates another bedroom and bathroom set. Thus, the standard of a dwelling unit is better reflected in the number of bathrooms. The largest samples IS, PM, GE, MV, and RI, with over $120 \mathrm{~m}^{2}$, have up to 4 or 5 bathrooms (Table 6).

\section{Dwelling Adaptation Analysis}

\section{(1) User's Needs and Renovation Purposes}

Observations revealed that the first adaptation is often related to assigning territory during the move-in stage and includes customization of interior components, such as furniture, bath \& kitchen equipment, fixtures, and cladding. Later, motivations could include family needs, such as adapting rooms to receive new family members, or repurposing empty rooms after one has moved away. However, in general, the main need is renovation and maintenance, primarily for interior cladding, bathroom and kitchen equipment, and home furniture (Fig. 6 \& Table 5).

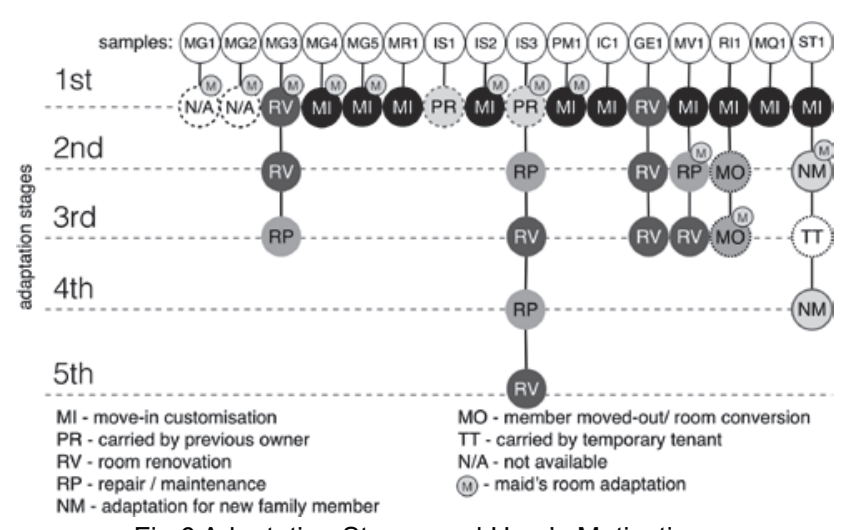

Fig.6 Adaptation Stages and User's Motivations

Table 5 Summary of Dwelling Adaptations and Management Methods

\begin{tabular}{|c|c|c|c|c|c|c|c|c|c|c|}
\hline $\begin{array}{c}\text { Sample } \\
\text { Code }\end{array}$ & 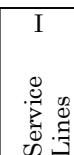 & 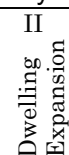 & 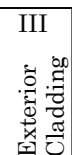 & 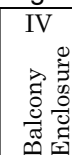 & 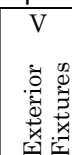 & 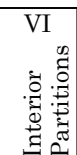 & 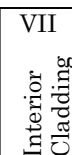 & 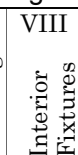 & 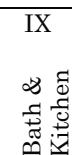 & 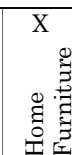 \\
\hline MG1 & B & & & & B & DB & B & DB & B & DB \\
\hline MG2 & B & & & & B & B & B & DB & B & DB \\
\hline MG3 & B & DBM & $\overline{\mathrm{DBM}}$ & DBM & $\overline{\mathrm{DB}}$ & $\overline{\mathrm{DB}}$ & B & DB & $\bar{B}$ & DB \\
\hline MG4 & $\bar{B}$ & & & & $\bar{B}$ & B & $\bar{B}$ & $\overline{D B}$ & B & $\overline{\mathrm{DB}}$ \\
\hline MG5 & DBM & $\mathrm{DBM}$ & DBM & DBM & DBM & DBM & DBM & DBM & DBM & DBM \\
\hline MR1 & B & & & & & & B & B & B & DB \\
\hline IS1 & & & & & DBM & DBM & DBM & DBM & $\overline{D B M}$ & DBM \\
\hline IS2 & DBM & & & & DBM & DBM & DBM & DBM & $\overline{D B M}$ & DBM \\
\hline IS3 & BM & & & & & $\mathrm{BM}$ & $\mathrm{BM}$ & & BM & DB \\
\hline PM1 & B & & & & $\mathrm{BM}$ & $\mathrm{BM}$ & BM & $\mathrm{BM}$ & $\mathrm{BM}$ & DB \\
\hline IC1 & & & & & B & B & B & B & B & DB \\
\hline GE1 & & $\bar{B}$ & & $\bar{B}$ & B & B & B & & $\bar{B}$ & $\overline{D B M}$ \\
\hline MV1 & DBM & & & & & B & DBM & DB & B & DBM \\
\hline RI1 & B & & B & & & B & B & DB & B & DB \\
\hline MQ1 & DBM & DBM & $\overline{\mathrm{DBM}}$ & DBM & DBM & DBM & $\overline{D B M}$ & DBM & $\overline{D B M}$ & DBM \\
\hline ST1 & & & & & & $\mathrm{DB} 1$ & $\overline{\mathrm{DB}}$ & DB & B & DI \\
\hline
\end{tabular}

*D-B-M: see Table $3 \square$ Self-Management; $\square$ Professional Management; 
Table 6 Apartment Adaptations Before and After (1-2)

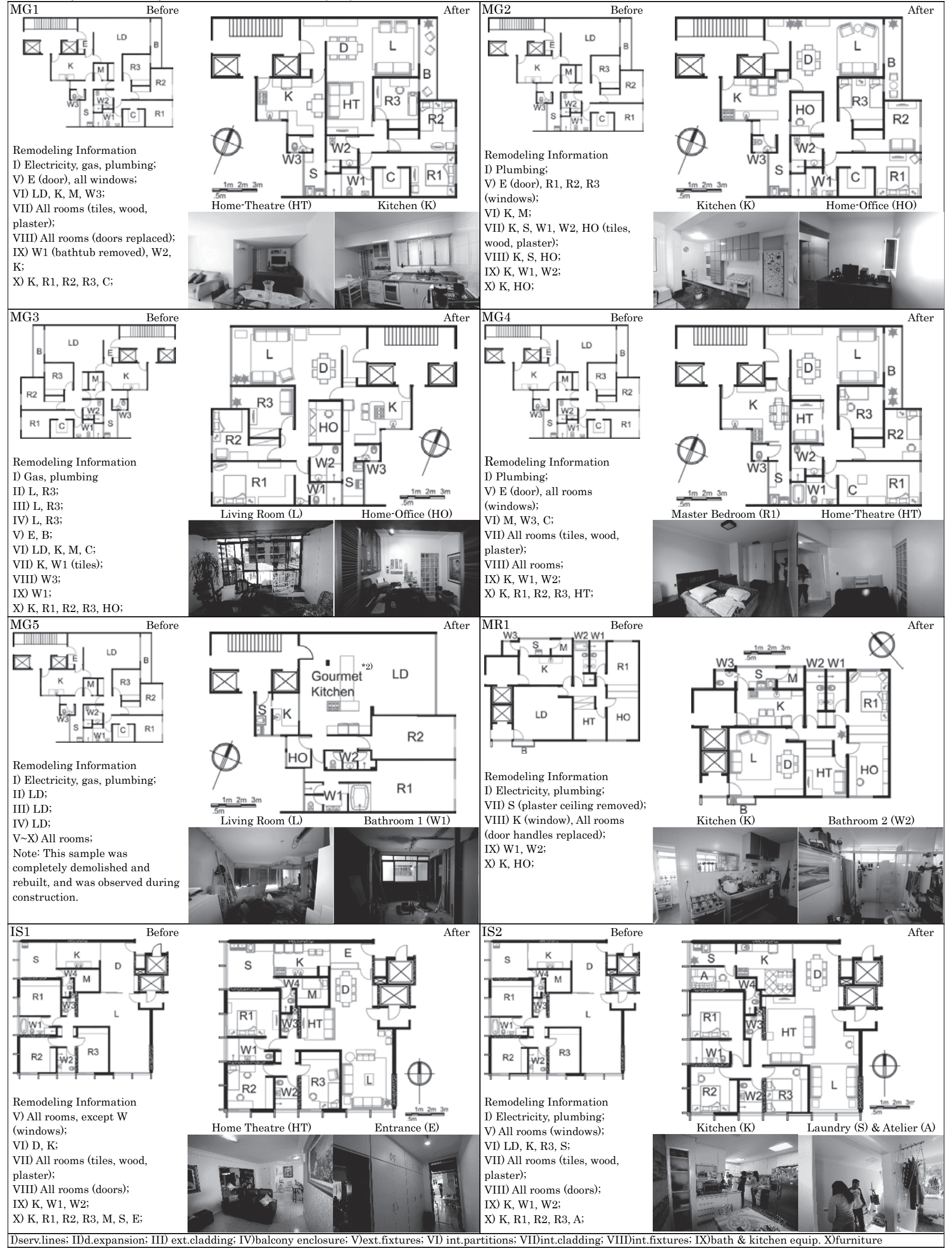


Table 6 Apartment Adaptations Before and After (2-2)

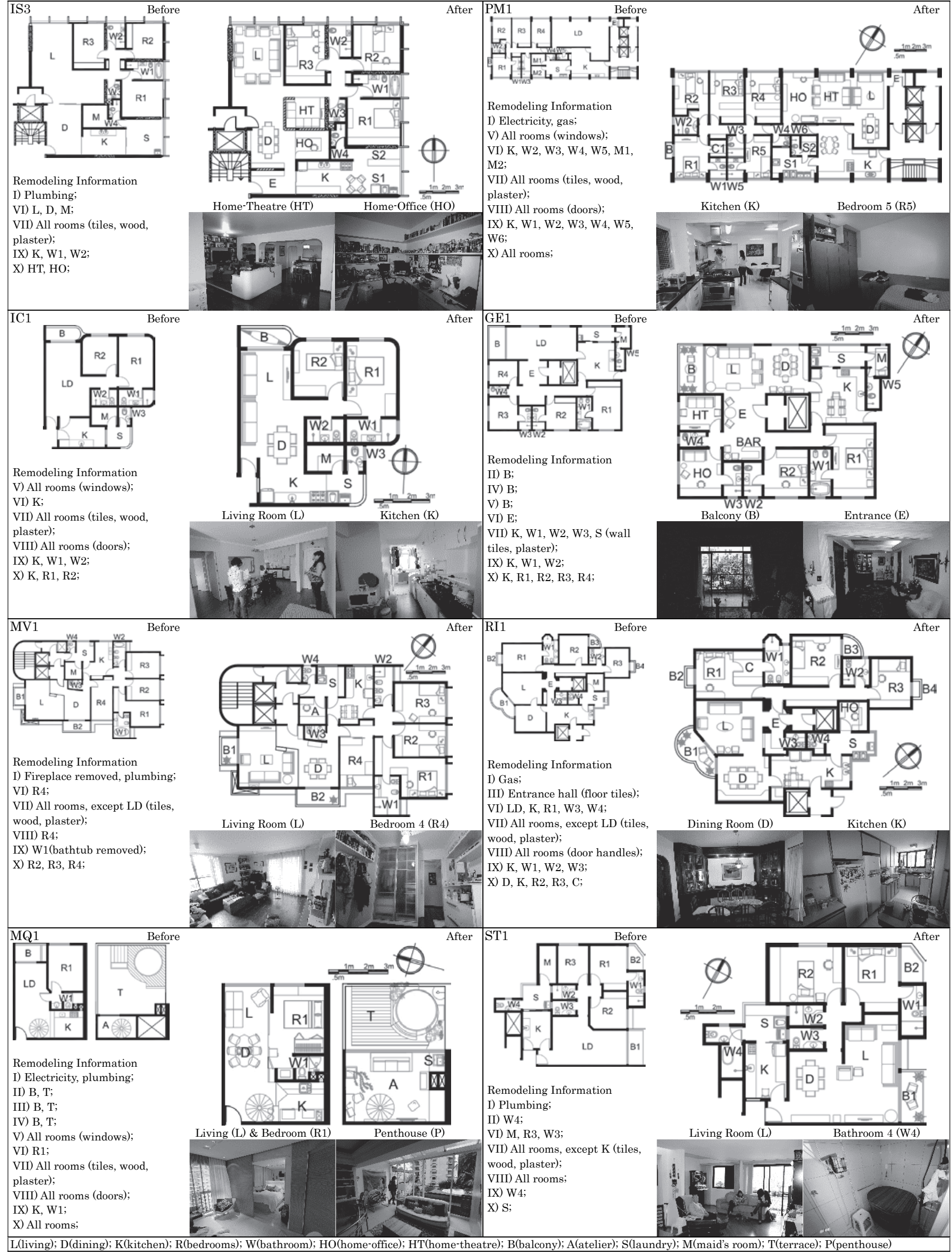




\section{(2) Maid's Room on the Way to Extinction}

Dwelling adaptations were not only due to family dynamics; there was also social change. Specifically, it was noted that the maid's room had been removed from 11 of the 15 samples $^{*}$ ) (Table 6, MG1 5; IS2; IS3; PM1; MV1; RI1; ST1), and it was judged essential to study the reasons and effects for this particular adaptation. Those maid's rooms that remain as originally planned could be explained by two reasons: either the maid still lives with the family (IS1), or the room is left when contiguous to a toilet or laundry room (MR1, IC1, GE1). The adaptations could be split into two cases: demolition to expand adjacent rooms or renovation for functional change (Fig. 7).
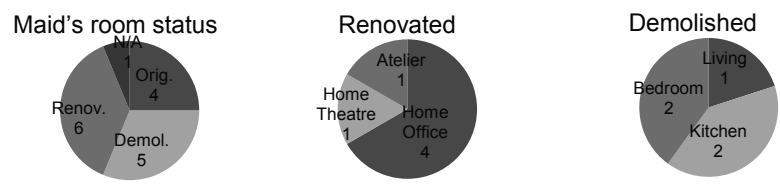

Fig.7 Maid's Room Adaptation

For most of its national history, Brazilians have been accustomed to an abundant domestic work force. Even before the abolition of slavery in 1888, it was commonplace for people from all races to migrate from the countryside to the cities in hopes of finding work with wealthy families, and thus escape poverty. The market for maids remained dependent on the unequal income distribution over various Brazilian regions and the numbers of uneducated people. These factors ensured a constant supply of people willing to work for very low salaries, enough to fit the budgets of middle-class families (Fig. 8).

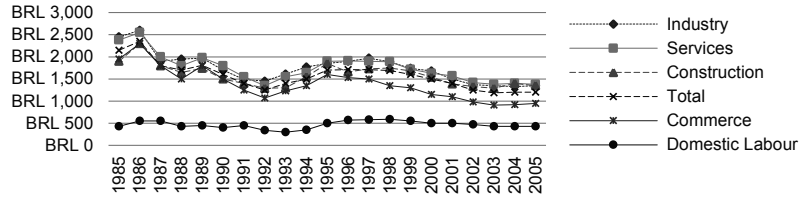

Fig.8 Domestic Labor Wage Compared to Others, Sao Paulo ${ }^{20)}$

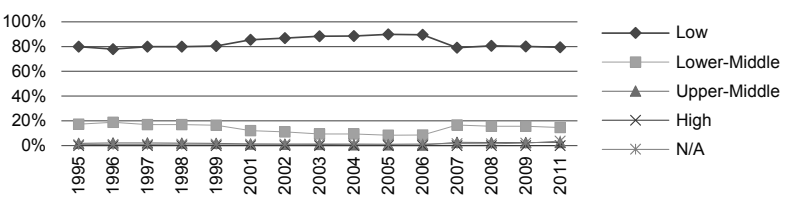

Fig.9 Relative Income Class Distribution in Brazil 1995-201177)

However, in the past decade, Brazil's professional classes have burgeoned and the lower-middle class has been growing. (Fig. 9). This has reduced the availability of cheap labor for domestic hires, and the maid's room design itself has come to be seen as reflecting obsolete values. As families stopped hiring servants, maid's rooms became available for other purposes. However, it should be noted that the room size is often not appropriate for some activities, and the maid's bathrooms, which is always paired with such rooms, might require pipe relocation ${ }^{* 6}$. As a result, depending on the layout, these tiny rooms are sometimes left idle or are simply utilized for storage.

\section{(3) SI System Division through Analysis of Individual Decisions}

In order to clarify SI system division in Brazil, we examined the range of individual decisions within different building levels. As a result, via fieldwork data analysis, several adaptation types were identified and classified as shown in Table 7.

Table 7 Adaptability According to the SI System Division ${ }^{* 7)}$

\begin{tabular}{|c|c|c|c|c|}
\hline SI Div. & Subsystem & Decision-making & Components & Adaptability \\
\hline \multirow{3}{*}{ Support } & $\begin{array}{c}\text { Base } \\
\text { Building }\end{array}$ & None & $\begin{array}{c}\text { Columns, beams, } \\
\text { foundations }\end{array}$ & Fixed \\
\cline { 2 - 5 } & $\begin{array}{c}\text { Common } \\
\text { Level }\end{array}$ & $\begin{array}{c}\text { Collective decisionWhaterproofing, ext. walls } \\
\text { (HOA agreements) }\end{array}$ & and cladding, elevators & Adaptable \\
\hline \multirow{3}{*}{ Infill } & $\begin{array}{c}\text { Boundary } \\
\text { Level }\end{array}$ & $\begin{array}{c}\text { Individ. decision } \\
\text { according to rules }\end{array}$ & $\begin{array}{c}\text { Window frames,entrance } \\
\text { hall, doors, balconies }\end{array}$ & Adaptable \\
\cline { 2 - 5 } & $\begin{array}{c}\text { Interior } \\
\text { Level }\end{array}$ & $\begin{array}{c}\text { Individual } \\
\text { decision }\end{array}$ & $\begin{array}{c}\text { Partitions, cladding, } \\
\text { fixtures, furnit; equip. }\end{array}$ & Adaptable \\
\hline
\end{tabular}

Figure 10 shows the rate of different dwelling adaptations in the 16 samples. According to the SI system theory as well as the Civil Code of Brazil ${ }^{*}$ ), adaptations on the left side of the chart should be more related to collective decisions, while adaptations on the right side should be more related to individual decisions. However, our observations have shown that all adaptations were the result of individual decisions.

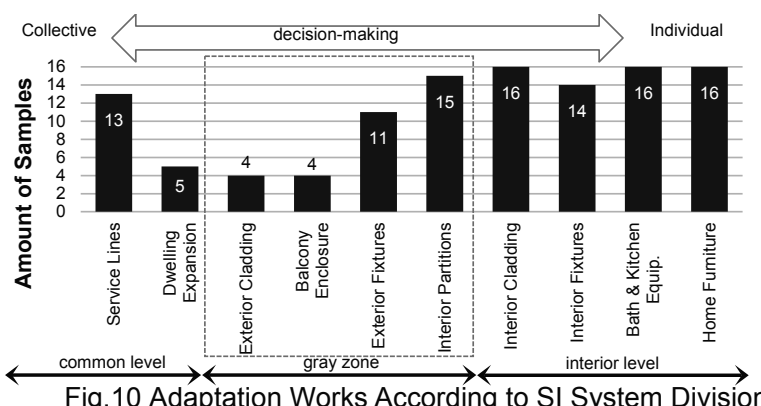

(4) Gray Zone of Decision and Policy Incompatibilities

Although condominium management policies in Brazil suggest a decision-making pattern similar to the SI system division, they are incompatible with the actual building process. For instance, partition elements should belong to the interior level and should be freely arranged according to individual decisions. Though, it is mainstream in Brazilian dwelling construction the use of loadbearing walls as partitions, with the same body of independent walls causing ambiguity between structural and non-structural parts. Therefore, a permit is necessary before partitions can be demolished.

Also, balcony enclosures are generally considered illegal because they can be seen as an addition of floor area. It is important to note that a balcony enclosure might include one or more of the following actions: (1) installation of an exterior glass sash; (2) removal of an interior glass sash; and (3) placement of floor cladding with the same material and height as the dwelling interior. Thus, the sum of (1) and (2), and/or (3) implies a dwelling expansion via modification of common level components, which would be considered illegal. But, in the case of (1) only, individual decision-making could be legal, if guided by common rules, as the originally proposed SI division. Hence, by confronting theory (SI 
division, legislation) and practice (actual construction methods), it could be assumed that interior partitions, exterior fixtures, balcony enclosures, and exterior cladding are within a gray zone between individual and collective decision-making (Fig. 10).

\section{(5) Self and Professional Management Analysis}

To assess the informality of the dwelling adaptation market, we investigated the involvement of technical expertise in SI adaptation. Adaptation management methods were arranged according to the contract type (Table 3). Then, through interviews, rates were established for each adaptation type. It is important to note that in samples (MG1), (IS1), (IS2), and (MQ1), the adaptations were overseen by a family member that was qualified in the construction sector. These cases were classified as designbuilding-management contract instead of do-it-yourself. The results revealed that the involvement of experts is more related to the common level (Fig. 11).

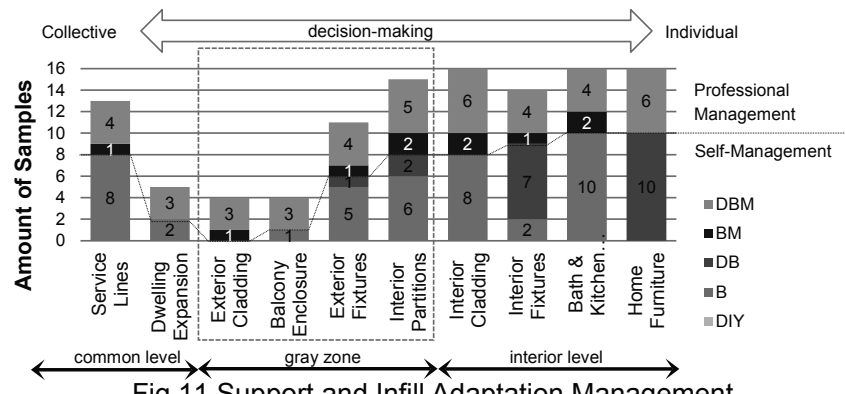

Fig.11 Support and Infill Adaptation Management

Note that support adaptations generally require technical expertise, but that our samples include cases of self-management at this level. It could be assumed that it may be difficult to hire a professional to handle these adaptations, since they are mostly illegal.

(6) Industrialization of Infill Components: Furniture

Depending on the production method, furniture could be classified into six types (Table 8):

Table 8 Furniture Production Classification

\section{\begin{tabular}{ll}
\hline Production & Definition \\
\hline DIY & Made and assembled by the dweller
\end{tabular}}

DIY $\quad$ Made and assembled by the dweller Self-Assembly Standard goods bought in parts to assemble (ex.: IKEA®)

Full Custom Made according to individual specifications (Made-to-order)

Semi-Standard Standard parts combined to custom made parts attend individual specifications (ex.: Furniture Makers in Brazil)

Custom Standard parts assembled according to individua

Assembly specifications (ex.: System Furniture)

Standard Standard parts and assembling in general

Built-in Built to be a permanent part of the building

Considering the bedrooms and kitchens of the units visited, we found that most furniture was custom-made, semi-standard, or built-in (Fig. 12). In the case of bedroom design, built-in furniture is more popular. Among these, there were seven cases where the furniture had later been adapted by carpenters.

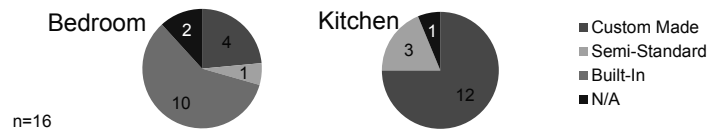

Fig.12 Bedroom and Kitchen Furniture Sampling
In the case of kitchen design, custom-made furniture was predominant, but semi-standard furniture is also very popular and different results can be obtained by including samples of other income strata. In semi-standard kitchens made in Brazil, furniture is usually roughly prefabricated in modules for later assembly. For instance, cabinet tops are often made of marble, thus requiring an on-site measurement, after the assembly stage, to provide a perfect fit. DIY and standard furniture are also popular in Brazil, but could not be found within these samples examined, probably because of the dweller age and income levels. However, self- and custom-assembly are not popular. Taken together, the market profile for furniture suggests a low level of industrialization that is highly dependent on skilled carpentry work.

\section{Conclusions and Recommendations}

(1) Regarding Home Adaptation in Brazil and Japan

The findings of this research revealed that the renovation purposes in Brazil are more related with the need for demarcating the family's territory during the move-in stage, and the need for preserving a home identity as the dwelling evolves along with the families' status.

Moreover, from the decision-making perspective, Japan's emphasis on safety prevents balconies from being remodeled for individual purposes. In the case of Brazil, however, even though there are laws governing the renovation of building boundaries, they do not always match the actual decision-making code enforced in condominiums. Since such laws are not being enforced, it could be assumed that the government is simply denying existence of any problem and is transferring related responsibilities to the dweller. Government oversight of balcony enclosures as a means to enable dwelling expansion could be seen as way to maintain a level of control in the process, and thus retard problems that might result from an excessive level of informal management, thereby ensuring safer adaptations.

Finally, the infill industry in Brazil shows clear signs of progress. However, the finishing parts still include a high amount of handcraft work within a scheme of coexistence of prefabrication and on-site construction. This could be explained by the remaining income gap that keeps the construction workforce affordable for members of the upper-middle class that live in apartments in the metropolitan area of Sao Paulo.

\section{(2) Recommendations for Open Building Implementation in Brazil}

Our observations on adapted apartments in Sao Paulo suggest that the Open Building concept should include flexible boundaries, with flexible facades, and pre-set design patterns, and should be implemented in a way that permits dwellers to enjoy decisionmaking freedom beyond the inner space of their homes while keeping condominium rules (Table 9). 
Table 9 Support Infill System according to Sao Paulo *7)

\begin{tabular}{|c|c|c|c|c|}
\hline & \multicolumn{2}{|c|}{ Support } & \multicolumn{2}{|c|}{ Infill } \\
\hline 4 parts & Base Building & $\begin{array}{l}\text { Common } \\
\text { Elements }\end{array}$ & $\begin{array}{l}\text { Boundary } \\
\text { Elements }\end{array}$ & $\begin{array}{l}\text { Interior } \\
\text { Elements }\end{array}$ \\
\hline Examples & $\begin{array}{l}\text { Columns, } \\
\text { beams, } \\
\text { foundations }\end{array}$ & $\begin{array}{l}\text { Waterproofing, } \\
\text { exterior walls, } \\
\text { cladding, elev. }\end{array}$ & $\begin{array}{l}\text { Window frames, } \\
\text { entrance hall, c } \\
\text { doors, balconies }\end{array}$ & $\begin{array}{l}\text { Partitions, int. } \\
\text { ladding,fixtures, }\end{array}$ \\
\hline Life Span & Long & & & \\
\hline Space Use & \multicolumn{2}{|c|}{ Common } & \multicolumn{2}{|c|}{ Private } \\
\hline Concern & \multicolumn{3}{|c|}{ Collective } & lual \\
\hline $\begin{array}{l}\text { Decision } \\
\text { Making }\end{array}$ & \multicolumn{2}{|c|}{$\begin{array}{l}\text { Small works: syndic } \\
\text { Large works: HOA }\end{array}$} & $\begin{array}{c}\text { Dwellers under } \\
\text { common rules }\end{array}$ & Dwellers \\
\hline
\end{tabular}

However, even though the management of boundaries and common elements in multi-story dwellings is covered by Brazil's national laws, the relationship between individuals or user groups within these boundaries may vary depending on the region. For instance, climate differences between the north and south of the country may implicate a different user relationship with balconies. Therefore, it is recommended a review of local building policies regarding the definition of boundaries and common elements be conducted. This way, the SI system could be used to prevent building and management problems, improve the quality of living, and assure longer life spans for residential buildings in Brazil. Moreover, in order to help build a housing system that will include a wider group of users, future works should consider other income groups, embrace a larger amount of adapted apartment samples and/or detached dwellings, and should cover the nation's five climatic subtypes.

\section{Acknowledgements}

This research was entirely supported by the Grant-in-Aid for Scientific Research of Ministry of Education, Culture, Sports, Science and Technology, Japan, grant number 22360247.

\section{Notes}

*1) According to Brazilian law (Civil Code, Art. 1331-1356; Condominium Act, law. 4191/1964), condominium management is led by a Syndic (chairperson) and an advisory board of three members elected among the householders. Management guidelines are set by the condominium Convention (master deed) and Bylaws (HOA document). Decisions are made during committee meetings, with the approval of a quorum fixed by condominium convention.

*2) A gourmet kitchen in Brazil is understood as a concept that involves integration with living and dining rooms, with the purpose of turning the act of cooking into a social event. Often related to high-income users, it does not replace the everyday kitchen.

*3) The homeowners were absent. The maid of (MG1) and the neighbor of (MG5) kindly hosted our visit.

*4) Monthly Wages in Brazilian Real (BRL) were converted to US dollar exchange value in Brazil at the moment of the survey and classified according to the World Bank Atlas income division of 2013.

*5) Sample MQ1 does not have a maid's room in its original plan.

*6) Typical buildings in Brazil have mechanical fixtures, wiring, pipes, and ducts embedded into the load-bearing structure. This makes pipe relocation or renovation difficult because the components are assembled with no regard to their different life cycles and/or the functional purposes in the building. Such as, bathroom pipes are built within cavities inside the bricks, covered with a layer of concrete, and then another layer of ceramic tiles. As a result, it is basically impossible to replace one component without disturbing its relation with other components, or demolishing them all completely.
*7) Adapted from: Japan. Ministry of Land, Infrastructure, Transport and Tourism: Skeleton Infill Housing, Skeleton Infill Bulletin, 2003.

*8) According to the Civil Code of Brazil, Art. 1,336, of the duties of condominium dwellers are as follows: I) To contribute to condominium expenses, according to their shares of the property; II) To refrain from any construction work that could compromise the building safety; III) To refrain from modifying the facade shape and color, as well as its parts, and exterior frames; IV) To maintain the original purpose of the building and refrain from using it in any way that would disturb peace, health, safety, and morality of others.

\section{References}

1) Habraken, N. J.: Supports, An alternative to mass housing, Urban International Press, UK, 2011

---: The Structure of the Ordinary, Form and Control in the Built Environment, ed. by Jonathan Teicher, MIT Press, Cambridge, 2000

2) Kobayashi H. et.al: Open Building for Developing Countries, A Multinational Approach..., Kaken Report, in Japanese, 2014

3) Kendall S., Teicher J.: Residential Open Building, Japanese ed. by Shin Murakami, Gihodo Shuppan, Japan, in Japanese, 2006

4) Sawada, S.: Open Building, Architecture for a Sustainable Society, Nikkan Kensetsu Tsushin Shinbunsha, Japan, in Japanese, 1998

5) Brandao, D. Q.: Diversity and Potential of Flexibility in Apartments Floor Plan Layouts, D. Thesis, Federal University of Santa Catarina, pp.176-214, in Portuguese, 2002

6) Nascimento, D. M. et.al: Designing Open Building for Social Housing..., In: Delft University of Technology: Changing Roles, New Roles, New Challenges, Netherlands, 2009.10

7) Malard, M. L.: Brazilian Low-cost Housing, Interactions and Conflicts Between Residents and Dwellings, D. Thesis, Univ. of Sheffield, 1992

8) Villa, S. B.: Living in Apartments, the Production of Private and SemiPrivate Spaces of Buildings in Sao Paulo Real Estate..., D. Thesis, University of Sao Paulo, pp. 34-134, in Portuguese, 2008

9) Booz Allen Hamilton: Study on the Model of Implementation of Housing Units Produced in Brazil, 2003, In: Centre for Management and Strategic Studies, CGEE: Prospective Study for the Construction Sector, Report, Brasilia, 104p, in Portuguese, 2009

10) Freitas, C; Nunes, B.: How and Why a Building Collapses, Veja, Retrieved from (http://veja.abril.com.br/noticia/brasil/como-e-por-queum-predio-desaba/), in Portuguese, 2012.1.27

11) Queiroz, T.: Building Collapse in Sao Bernardo, Veja, Retrieved from (http://veja.abril.com.br/multimidia/galeriafotos/desabamento-em-saobernardo-do-campo-2012/), in Portuguese, 2012.2.7

12) Palermo. C.: The Social Sustainability of Dwelling, Da Autora, Florianopolis, in Portuguese, 2009

13) Organization of American States. Primer on Natural Hazard Management in..., 1991, Retrieved from (https://www.oas.org/dsd/ publications/Unit/oea66e/begin.htm) on 2014.1.16

14) The Economist: The Expanding Middle Class in Latin America, Retrieved from (http://www.economist.com/news/americas/21565930decade-social-progress-has-created-bigger-middle-classbut-not-yetmiddle-class), 2012.11.10

15) Centre for Management and Strategic Studies, CGEE: Prospective Study for the Construction Sector, National Report, Brasilia, 104p, in Portuguese, 2009

16) Bonduki, N. G.: Origins of Social Housing in Brazil, FAPESP, Sao Paulo, in Portuguese, 1998

17) Brazilian Institute of Geography and Statistics, IBGE: Demographic Census, 2010, Retrieved from (http://www.ibge.gov.br) on 2012.12

18) Sao Paulo. City Hall. Municipal Healthcare Department: Bulletin of Demographic Census 2010, in Portuguese, 2012.11

19) Warouw, F.: A Study of Open Building System for Multi-Story Housing in Indonesia, D. Thesis, Chiba University, pp.177-178, 2011

20) Sao Paulo. Municipal Planning Department. SEMPLA. Division of Statistic and Information, DIPRO: Observing Sao Paulo, Urban Contrasts, Sao Paulo, 64p, in Portuguese, 2004 


\section{1. はじめに}

ブラジルでは、中所得者向けマンションでもプールなどの共用施 設が充実している点が特徴であり、1990 年代以降はますますその傾 向を強めている。マンションの住戸改造においては、入居者自身が 内容を決めて工事のみ職人に発注するセルフ・マネジメント方式 （自己発注方式）が一般化している。そのため、改造時に構造壁を 破壞してしまう例が多数存在する。そこで本研究では、サンパウロ 市の集合住宅における住戸改造実態を把握し、スケルトンとインフ イルの区分と住戸改造に対する住要求について明らかにすることを 目的とする。

\section{2. 調查概要}

サンパウロ市中心部の中高所得者向けのコンドミニアムを対象に、 住戸改造の経験がある 10 団地 16 住戸の調查を行った。住戸の改造 内容および方法、管理規約上のルールなどについての居住者へのヒ アリング調查、実測による図面作成、住戸と団地内のカメラ撮影な どを行った。また、新築時の個別対応および工事内容などを把握す るため、マンションのディベロッパーにヒアリングを実施した。調 查期間は、2012 年 7 月 11 日から 31 日までである。

\section{3. 調査結果}

\section{$3-1$. 新築段階の個別対応}

ブラジルの建築制度は日本に比較的近かった。建築許可を取得後 にマンション販売が行われ、販売と並行して建築工事、インフィル 工事へと進んでいた。完了検查後に入居と登記という流れになる。 引渡し前は、カスタム建設と呼ばれ、ディベロッパーがセミオプシ ヨンとして簡易な個別対応のメニューを提供し、住人はその中から 間取りと内装の仕上げなどを選択することができる。引渡し後は、 セルフ・マネジメント方式によって対応することが多かったが、特 に各業者との契約タイプによってマネジメントの対応が異なること がわかった（表 3 )。

\section{3-2．事例住戸の属性}

調查対象の居住期間は、2 41 年で幅広く、築年数は $23 \sim 44$ 年で

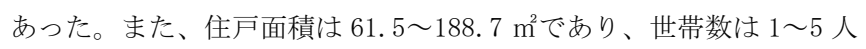
であった。対象世帯の半数は定住を希望しており、その主な理由と しては、子育てのための広い空間、義理の母親との近居などが上げ られていた。

住戸の間取りは、3 室部屋のタイプが $60 \%$ 占めており、主寝室 にはバスルームが付いていた。また 10 事例ではメイドの部屋が別途 に設けられていた。

\section{3-3. 住戸改修の特徴 \\ (1)メイド部屋の変更と理由}

メイド部屋があった 11 事例の全てに、メイド部屋の用途がなくな っていた。その理由としては、今は常駐するメイドがいなく、部屋 が小さくトイレとペアになっているために、通常の家族のための居 室として使用できず、SOHO、ホームシアターなどの多目的な空間へ と変更されていた。しかし、限られた大きさのままで、貯蔵室また は未使用の空間のままで残っている事例もあった。

\section{(2)バルコニーの改修と意思決定}

室内改修は一般的であり、さらに、一部ではバルコニーの簡易な 室内化がみられた。ただし、景観に影響しない範囲で透明ガラスを 入れる程度であり、目立つ空枠やカーテンを設置すると法律上室内 とみなされるため容積率オーバーになっている。このため、そのよ うな改造は原則として禁止されていた。

\section{(3)セルフ・マネジメント方式}

入居後の個別対応は広く行われており、壁のペンキ、床の仕上げ 材の変更は一般的であった。また、その方法として、セルフ・マネ ジメント方式が多かった。この傾向は収入にかかわらず同じであり、 手間をかける習慣が広く定着していると考えられる。

\section{(4)家具の工業化}

事例での家具作りは、寝室では造り付け家具が 10 事例で最も多く、 キッチンはカスタム・メイドが 12 事例で最も多かった。ブラジルで は DIY や既製品が一般的に普及されていることから、これらの結果 は、今回の調查対象の所得や年齢が影響を与えていると考えられる。

\section{4. まとめと課題}

ブラジルでは、インフィル部においてある程度まで工業化が進み つつも、住宅部品は質が悪いものとみなされ普及は限定的であるこ とがわかった。その品質向上が課題であろう。また、S と I の区分 が不明確な中で自己発注方式が一般化しているため、改造時に構造 壁を破壞してしまう例が存在することがわかった。このような危険 行為の改善のためにS I 概念の定着が求められ、ブラジルに適した SI 区分について提示した。

(2014 年 6 月 10 日原稿受理, 2015 年 4 月 15 日採用決定) 